УДК 624.131.541.3

В.О. Галушко, докт.техн.наук, доцент,

О.М. Галушко, канд.техн.наук, доцент,

І. В. Колодяжна, Д.Ю. Уваров, А.С. Уварова,

Одеська державна академія будівництва та архітектури, м. Одеса

\title{
СУЧАСНІ СПОСОБИ УКРІПЛЕННЯ ГРУНТУ ПРОТИ ЗСУВУ
}

\begin{abstract}
Анотащія. В статті розллянута проблема територї під приватне житлове будівництво, яка наразі є однією з актуальнишіх. У минулому столітті велося масове будівництво будинків $i$ споруд на таких територіях. Міста розросталися й території під забудову займалися поблизу балок, водойм. Для садибного будівництва нахилені поверхні себе добре зарекомендували, тому малоповерхове будівництво житлових поселень на склонах є достойною альтернативою. Несвоєчасні ремонти трубопроводів, викидання сміття в прилеглі балки $і$, як наслідок, підйом рівня грунтових вод призвели до виникнення зсувів на таких територіях. Метою даної статті є вибір ефективного методу закріплення схилу від зсувів. Тому завдання зводиться до вибору ефективної технології для зміцнення грунту проти зсуву.
\end{abstract}

Ключові слова: сучасні технологї закріплення грунтів, способи та методи укріплення грунтів, зсув.

Вступ. Проблема території під приватне житлове будівництво наразі є однією з актуальнишіх. Центральні частини населених пунктів вже забудовано і земельні ділянки для забудови пропонується на окраине. Альтернативою є забудова склонів в межах населених пунктів, на берігах річок та склонах.

Для садибного будівництва нахилені поверхні себе добре зарекомендували, тому малоповерхове будівництво житлових поселень на склонах є достойною альтернативою.

До основних недоліків склонів відноситься в більшості виподків складні грунтові умови, що потрібує закріплення грунтових мас. 3 одного боку це збільшує собівартість житла, а 3 іншого - дає можливість створення оптимальних архітектурних рішень в плануванні територій.

Геоформування ухилів відбувалося на різних територіях за різних обставин, тому і методи закріплення грунтів відрізняються та залежать від конкретної геології. Це також дає можливість створення варіативних архітектурних рішень у плануванні територій.

При виборі ефективного способу для укріплення грунта необхідно розглянути в комплексі основні показник такі як: стан грунтів, провівши інженерно-геологічні вишукування, розглянути технологічні процеси $з$ можливими механізмами, які можливо виконати для конкретного об'єкта, їх вартість і тривалість.

Тому актуальність полягає в комплексному підході вибору ефективного способу зміцнення схилів.

Аналіз досліджень і публікацій з проблеми. Укрепления склонами занимались наступні вчені і фахівці різних країн в тому числі - Терьохін Є. Ф., Авербах І.В., Гладкий В.М., Саприкін Л.Д., Філахтов А.Л., Янкулін М.Г., Давидов Г.Д., Дмитрієв С.А., Мулин Н.М., Баженов Ю.М., Баранов В.С., Горчаков Г.І., Алімов Л.А., Воронін В.В., Захаркін В.М., Розумний В.В., Копейко В.Я., Мещеряков А.Н., Хейфец В.Б., Перлей Е.М., Раюк М.І., Шик С.П., Ржаніцин Г.А., Горбунов-Посадов М.І., Іллічов В.А., Крутов В.І., Сорочан Е.А., Трофіменков Ю.Г., Гольдштейн М.Н., Дудінцева М.О. і ін.
Українські вчені: Філахтов А.Л., Ткаченко Р.Н., Янкулін М.Г., Писанко Н.В., Чернухін А.М., Шейнблюм В.М., Менейлюк А.І., Бічев I.К і ін.

Закордонні фахівці: Parkas J., Hujecek O., Balko C., Sloboda P., Bolton M.D., Cheney J.A., Kutter B.L., Cundall P. A., Drescher A., O. D. L. Strack., Dysli M. та інші.

Постановка завдання. Мета полягає в розгляді сучасних способів зміцнення схилів як для окремо вартих будинків, так і зведених на схилах уздовж берегової лінії.

Для досягнення мети були поставлені наступні завдання: вивчити існуючі сучасні способи зміцнення схилів, вказавши їх область застосування, розробити класифікацію способів і методів зміцнення, зрівняти техніко-економічні показники.

Основна частина. Зсув - відрив грунтового масиву та шарових новоутворених грунтів та зміщення їх по схилу під дією сил тяжіння.

На підставі літературних джерел, інженерних розв'язків складена класифікація способів зміцнення схилів рис. 1, 2. До основних технологій закріплення склонів відносяться наступні методи та технології, які вказані у класифікації, що наведено нижче 1, 2, 3 :

Нижче розглянемо структури зміцнення схилів рис. 3.

Як приклад розглянемо котеджне селище в зсувній зоні побудований на ріці Дніпро м. Запоріжжя. Із представлених структурних схем зміцнення схилів у нашому випадку підходить варіант b (утримування висоти схилу). Даний метод дозволяє виконувати вертикальне закріплення двома способами: стіна в грунті й підпірна стіна. Альтернативним варіантом може бути в нашому випадку - $\mathrm{d}$ (комбіновані методи). У цьому випадку ми можемо використовувати вже кілька способів зміцнення схилів. А саме: стіна в грунті, підпірна стіна, габіони, контрбанкети й контрфорси. Нижче розглянемо кожний із цих варіантів указавши їх область застосування й техніко-економічні показники. На рис. 4 показаний план розташування котеджного селища. 


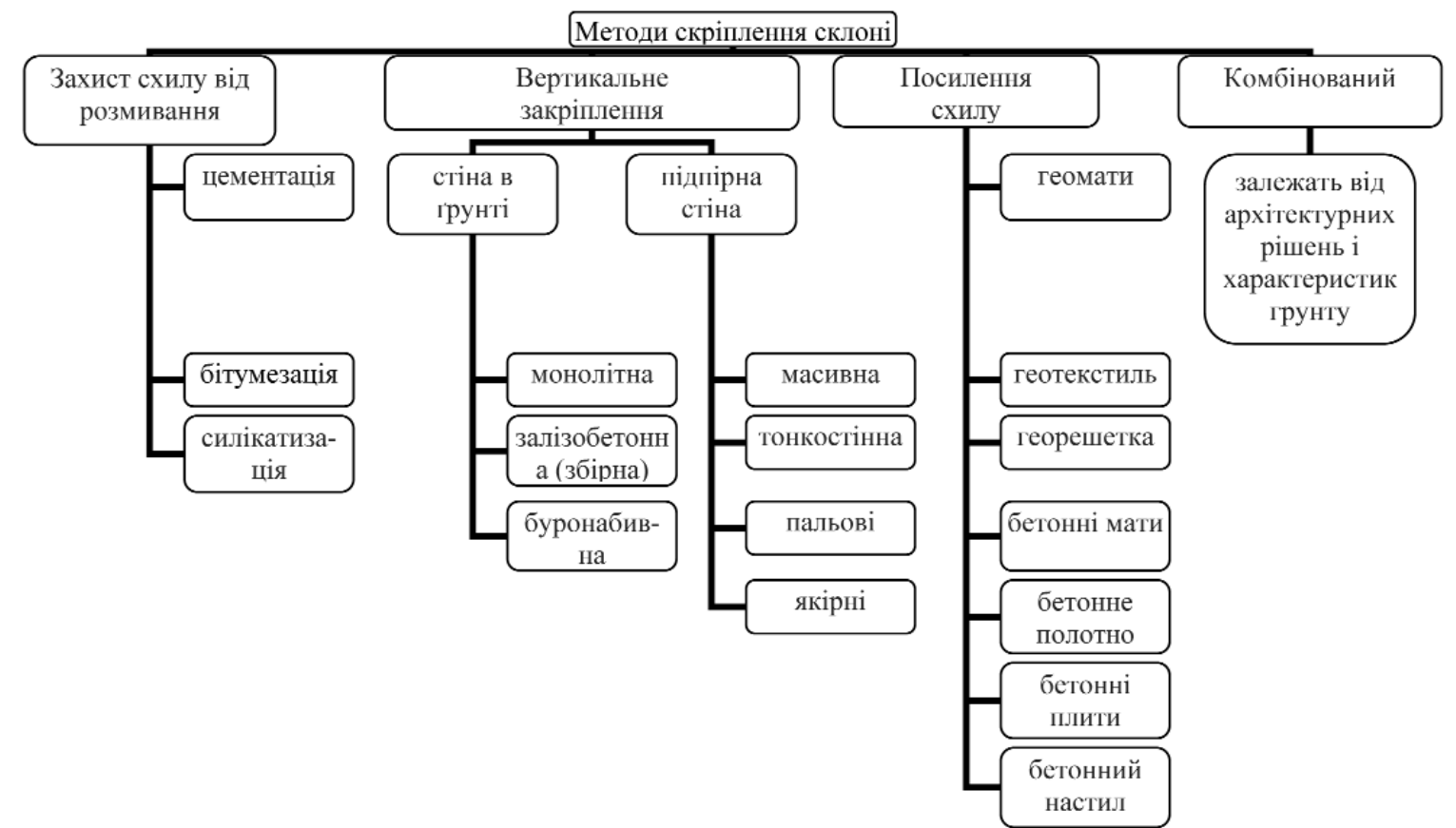

Рис. 1. Класифікація методів скріплення схилів

Розглянута ділянка складається із чотирьох майданчиків різних рівнів. Для втримання масиву грунту й запобігання зсуву розглянемо способи зміцнення схилів.

Одним з відомих способів зміцнення схилів є "Стіна в грунті".

Технологія зведення "Стіни в грунті" складається з наступних процесів: 1. буріння шпар, свердловин; 2. розробка траншеї (шириною 0,4-1,0м), з глини- стим розчином; 3. монтаж арматурних каркасів; 4. монтаж монолітної труби або збірного залізобетону; 5. подача бетонної суміші.

На рис. 5 представлені фрагменти виконання стіни в грунті. [6]

Технологія "Стіна в грунті" може бути виконана декількома способами: траншейним і пальовим.

Так як котеджне селище зведене на штучно створеному схилі, ефективним способом в нашому

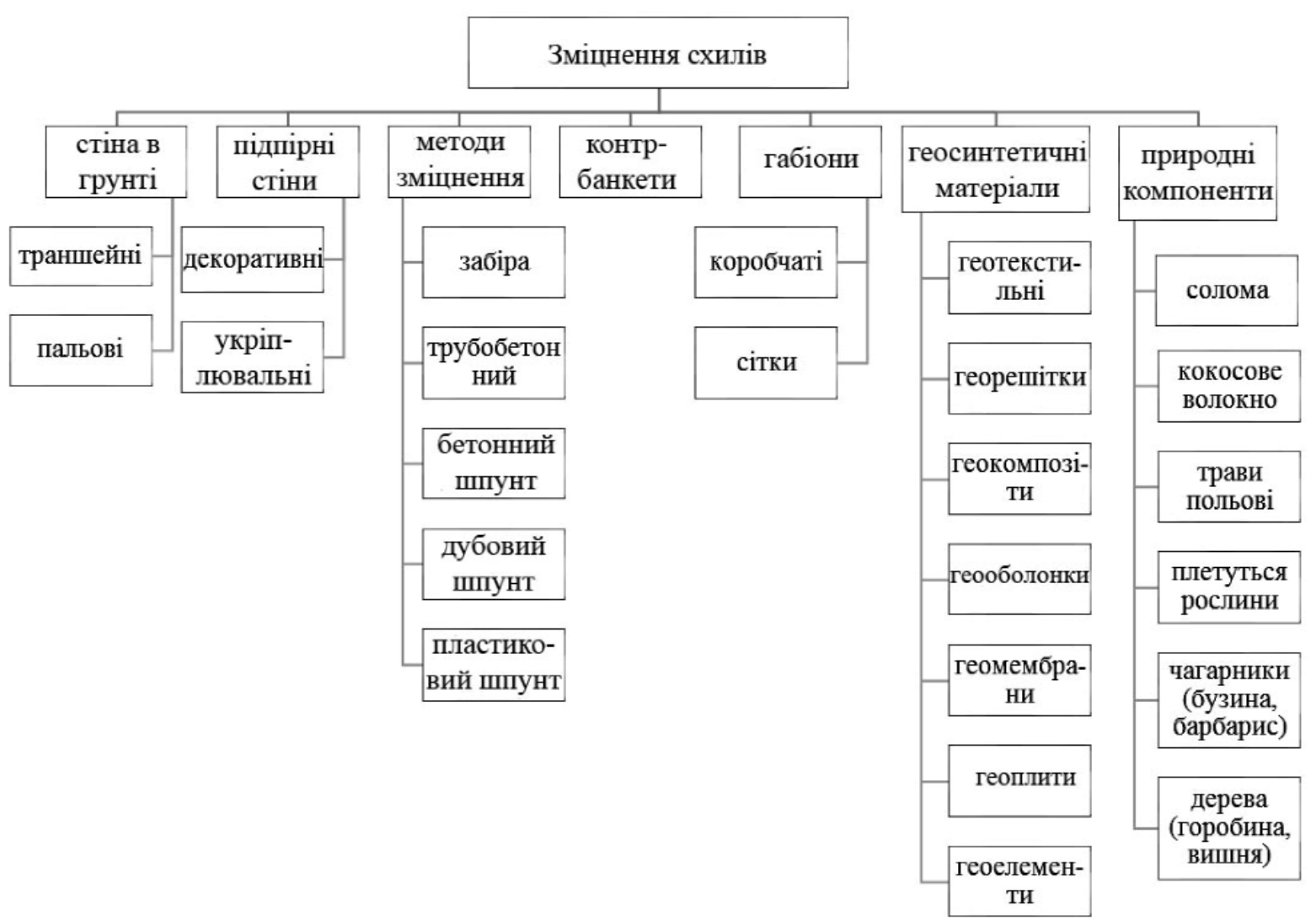

Рис. 2. Класифікація способів зміцнення схилів і берегових ліній 


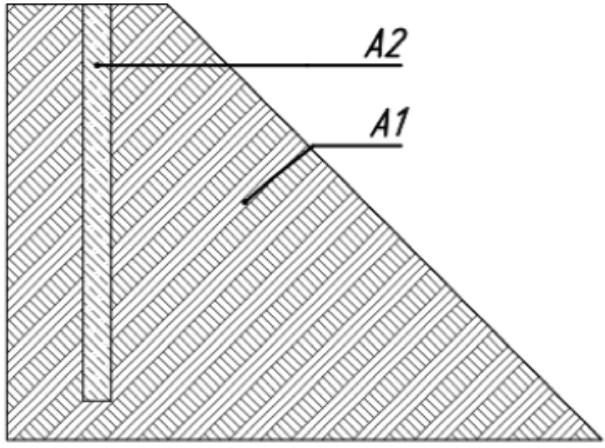

а) захист схилу від розмивання: А1 - схил, що закріплюється; А2 - стіна в грунті

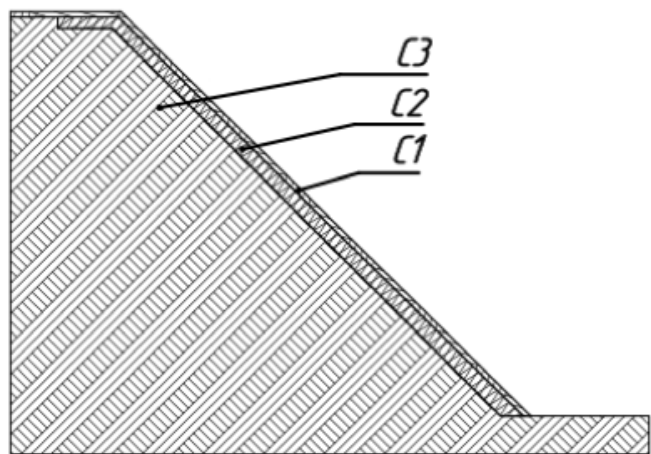

с) зміцнення схилу: С1 - родючий шар; С2 - геозакріплення; С3 - схил, що закріплюється

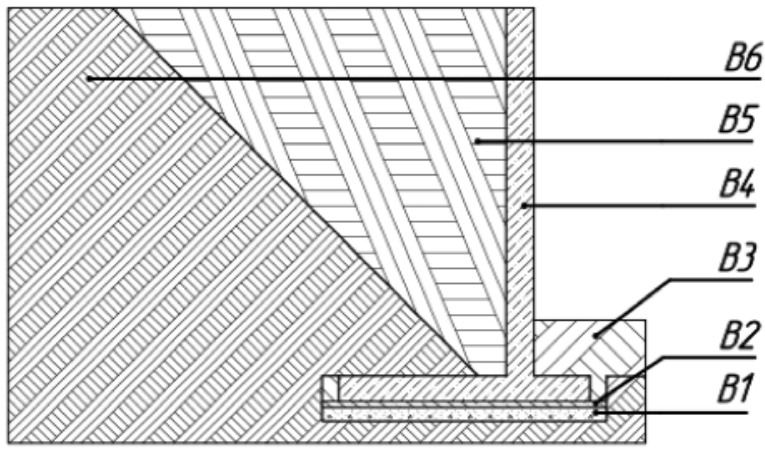

b) утримування висоти схилу: В1 - щебнева подушка; В2 - бетонна підготовка; В3 - зворотня засипка; В4 підпорна стіна; В5 - засипка схилу з дренажом; В6 - схил, що закріплюється

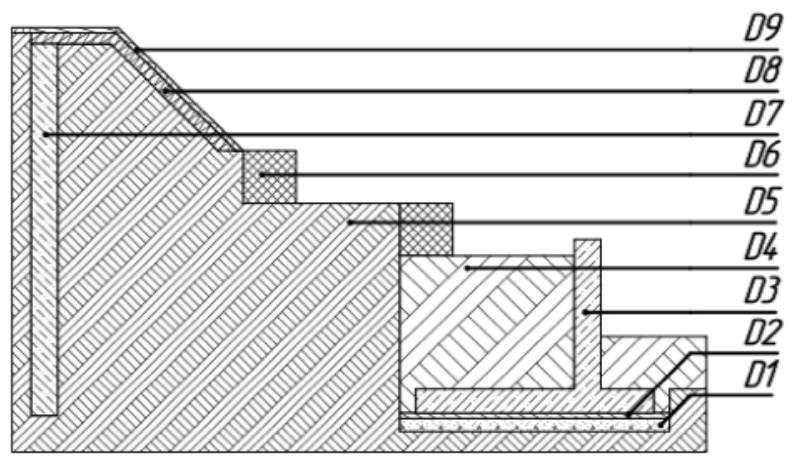

d) комбіновані методи: D1 - щебнева подушка; D2 - бетонна підготовка; D3 - підпорна стіна; D4 - засипка схилу з дренажом D5 - схил, що закріплюється; D6 - габіони; D7 - стіна в грунті; D8 - геозакріплення; D9 - родючий шар;

Рис. 3. Структури скріплення схилів

випадку буде пальовий.

Траншейний спосіб виконується з використанням монолітного бетону й залізобетонних секцій, за допомогою яких формується єдина стіна.

Пальовий спосіб виконується з буронабивних опор, які розташовуються одна до одної в ряд. Вони дозволяють сформувати міцну конструкцію, що огороджує відповідну ділянку (рис. 5).

Техніко-економічні показники на пристрій "Стіна в грунті" на 1м становлять:

- Вартість робіт - 9500 грн./м ${ }^{3}$

- Працезатрати робітників - 3,88 чіл.-дн.

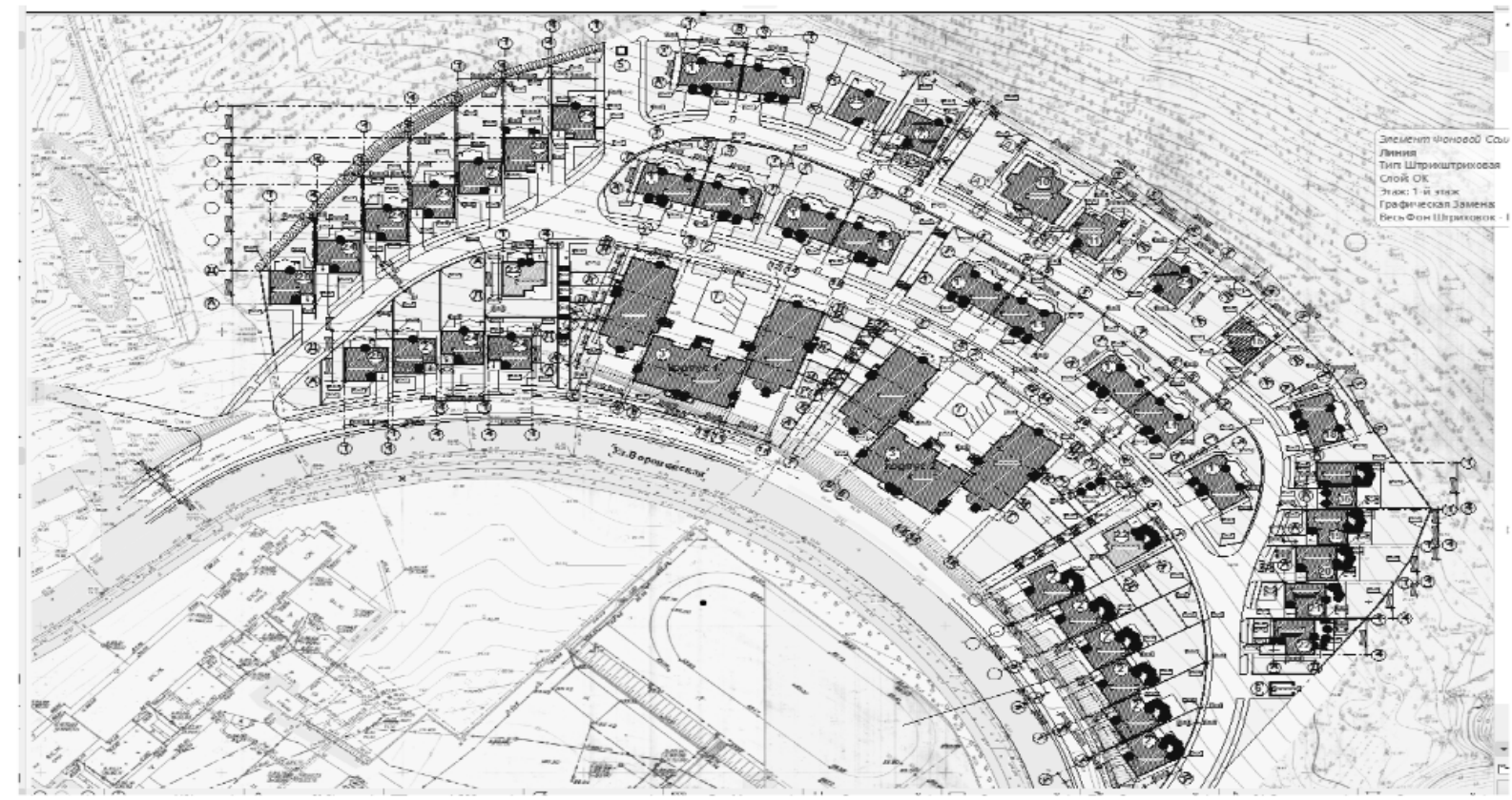

Рис. 4. План розташування котеджного селища 


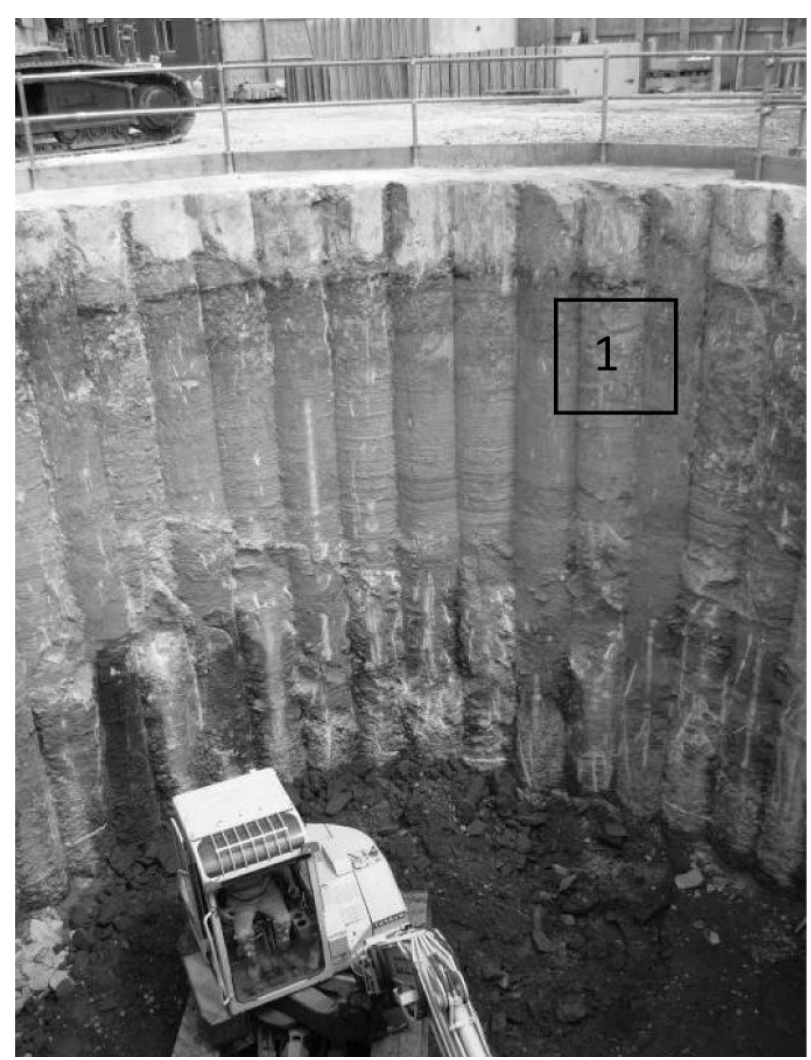

Рис.5. Фотофрагмент виконання готового зміцнення стіни в грунті пальовим способом 1 - палі

- Машинного часу $-1,58$ маш.-змін.

- Виробіток на один робітника - 0,26 маш.-зміну.

- Тривалість виконання робіт - 68,8 ч-см.

Наступним є спосіб зміцнення схилів підпірними стінами. Незалежно від призначення, підпірна стіна має 4 елементи: 1 - фундамент; 2 - тіло; 3 дренажну систему; 4 - систему водовідведення.
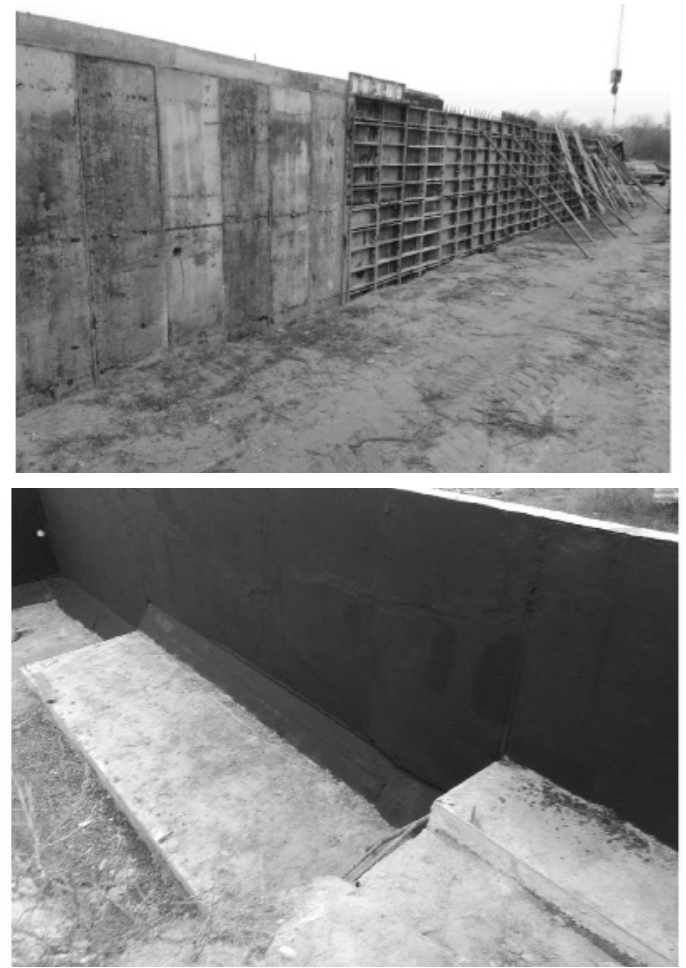

По способу виконання підпірної стінки діляться на:

- виконання основи без підготовки (штучний мареріал бут); основі;

- виконуються на попередньо підготовленій

- виготовляються на стрічкових фундаментах (фундамент мілкого закладення);

- виготовлення на фундаментах глибокого закладення (пальові фундаменти).

У нашому прикладі технологія зведення "підпірної стіни" складається з наступних процесів:

I. Підготовчі роботи

- геодезична розбивка осей на місцевості;

- розробка грунту;

- планування підстави котловану;

- пристрій дренажної системи;

- влаштування вкладишів обалубки для пристрою бетонної підготовки; стіну;

- пристрій бетонної підготовки під підпірну

II. Роботи із пристрою фундаменту й нижньої частини підпірної стіни:

- установка опалубки під пристрій фундаменту й виготовлення нижньої частини стіни;

- установка арматурної сітки й каркаса фундаменту й виготовлення нижньої частини стіни;

- подача бетону в опалубку для виготовлення фундаменту й нижньої частини стіни;

- ущільнення бетонної суміші;

- разопалубовання щитів для виготовлення фундаменту й нижньої частини стіни;

III. Роботи із пристрою підпірної стіни верхньої частини:

- установка опалубки для виготовлення верхньої частини стіни;

- установка арматурного каркаса для виготовлення верхньої частини стіни;
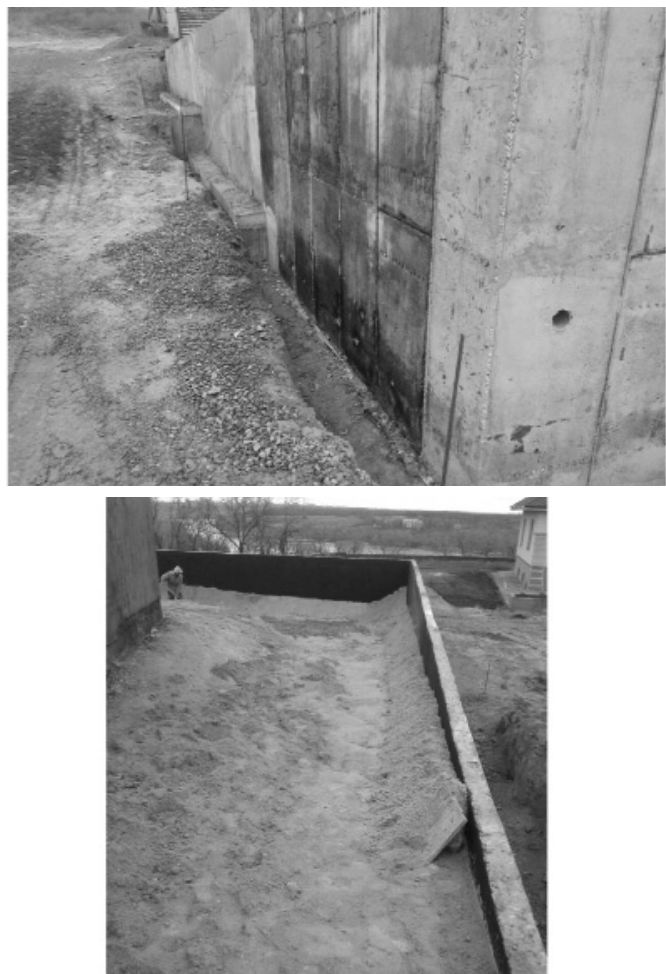

Рис. 6. Фото-фрагменти виготовлення підпірної стіни 
- подача бетону в опалубку для виготовлення верхньої частини стіни;

- ущільнення бетонної суміші;

- розопалубовання щитів для виготовлення верхньої частини стіни;

У запропонованому способі при влаштуванні підпірної стіни використовувався портальний пристрій розроблений авторами. На рис. 7 представлений пересувний портальний пристрій, що полягає 3 2х модулів.

Для вільного переміщення по місці виконання робіт "Портал" переміщається по рейках, які укладаються на шпали, покладені на схилі.

У верхній частині балки "Порталу", установлюються переносні домкрати. "Портал" має градуйований елемент у вигляді зубчастої півсфери, на ходовому візку, до якого можуть кріпитися ківш для видалення грунту й гаки при монтажі опалубки й арматурної сітки 7 .

По проекту передбачене двох-ярусна підпірна стіна. У зв'язку із цим конструктивні елементи нарощуються, з'єднуючи нижній ярус підпірної стіни 3 верхнім.

Виконання такелажних робіт здійснюється за допомогою лебідки, з остановами, які включають храпове колесо, вал, собачку, вісь, пружину, різного типу захвати й ін. Ці пристрої не перешкоджають підйому вантажу, але виключають можливість його непередбаченого спуска під дією власної ваги (рис. 8, 9).

3 метою кріплення опалубки в проектне положення, установлюють по верхньому поясу полиці, так званий, монтажний домкрат, а під ним, впритул, технологічний домкрат. У цьому випадку один домкрат забезпечує тверде кріплення порталу при роботі, а другий забезпечує вертикальне положення опалубки при подачі бетонної суміші. Таке з'єднання на майданчику не має потреби в додатковому посиленні несучої конструкції.
Технологія роботи з "Порталом" наступна. Для виготовлення нижньої частини підпірної стіни до порталу кріпиться ківш, що дозволяє видаляти зайвий грунт. Далі за допомогою лебідки встановлюється опалубка, у яку опускається сітка. Після подається бетон (рис. 10).

При підйомі щитів опалубки й арматурної сітки, для втримання використовуються кліщі, лебідки або захвати (рис. 8, 9).

Для втримання вантажу у висячому положенні використовують фіксатор (рис. 9), наявний на лебідці.

Переваги розробленого конструктивно-технологічного рішення полягають у наступному:

- підвищуються продуктивність праці й ступінь механізації виробничих процесів, знижуються витрати;

- вага "Порталу" дозволяє робітникам виконувати монтаж конструктивних елементів вручну без механізмів;

- завдяки можливості переміщати його в зборі по рейках при переході на іншу стоянку не потрібен демонтаж і монтаж;

- наявність шарнірного з'єднання блоку й підлоги-блоку дозволяє виконувати роботи одночасно 3 декількох стоянок;

завдяки наявності навісного устаткування, можливо, виконувати повністю підпірну стіну не залучаючи інші механізми.

Техніко-економічні показники на пристрій підпірної стінки становлять:

- Вартість робіт - 7000 грн

- Працезатрати робітників - 1936,6 чіл.-год.

- Машинного часу - 438,14 маш.-год.

- Виробіток на один робітника $-1,57$ м/зміну.

- Тривалість виконання робіт - 36 зміни.

Спосіб зміцнення схилів габіонами. Габіонні конструкції є одними із традиційних способів захис-
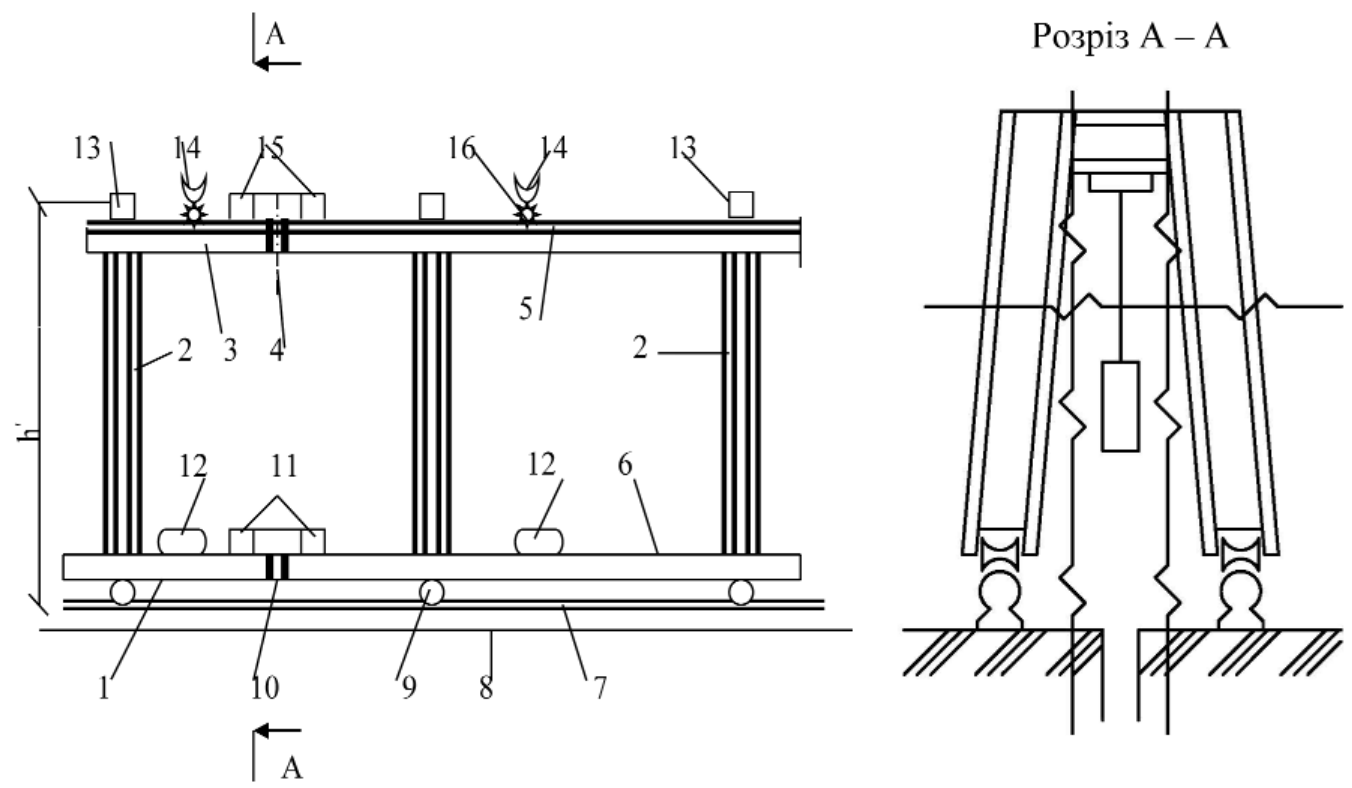

Рис. 7. Пересувний портальний пристрій складається з 2-х модулів:

1 - нижня жорстка полиця, 2 - стійка, 3 - портал $(1 / 2,1 / 4) \mathrm{M}, 4$ - шарнірне з'єднання верхня, 5 - портал (M1), 6 сполучна нижня полиця, 7 - рейки, 8 - шпали, 9 - колесо, 10 - шарнірне з'єднання нижнє, 11 - сполучні планки, 12 захват, 13 - домкрати, 14 - градуйований елемент, у вигляді зубчастої півсфери, буровий пристрій, 15 - сполучні планки, 16 - ходові візки, 19 - стійка з нахилом, 20 - лебідка, 21 - верхня підсилююча балка - полиця 


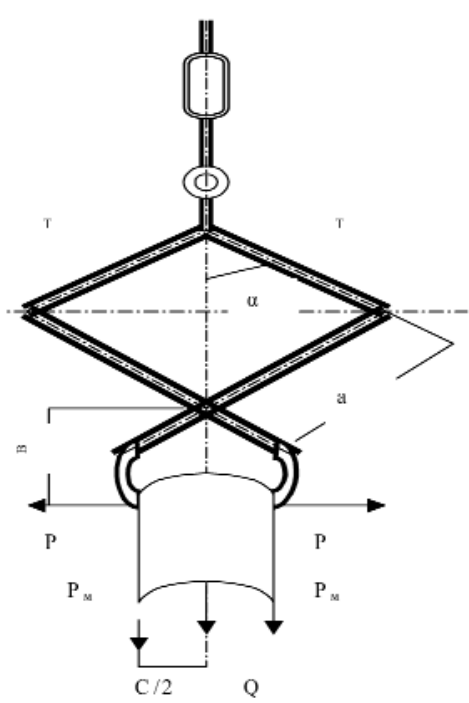

Рис. 8. Захвати кліщі

ту земель порушених водною ерозією, які використовуються вже більш 100 років. Вони призначені для захисту земель і споруд від небезпечних природніх гідрометеорологічних, геологічних і антропогенних процесів, у т.ч. руслової, схильної, ярижної й хвильової ерозії, зрушень 4 .

Технологія зведення "габіонами" складається 3 наступних процесів: 1 - Зрізка укосу; 2 - Розробка грунту згідно із проектом; 3 - Доставка коробчатих габионів; 4 - Монтаж коробчатых габионов у проектному положенні; 5 - Кріплення коробчатих габионов металевими анкерами; 6 - Заповнення коробчатих конструкцій каменем; 7 - Зворотне засипання пазух.

Техніко-економічні показники на пристрій габіонів становлять:

- Вартість робіт - 10710 грн.

- Працезатрати - 480,00 чіл.-год.

- Машинного часу - 153,00 маш.-год.

- Виробіток на один робітника - 1,3 м/зміну.

- Тривалість виконання робіт - 15,4 зміни.

Спосіб зміцнення схилів контрбанкетами. Контрбанкет - інженерне спорудження з каменю або

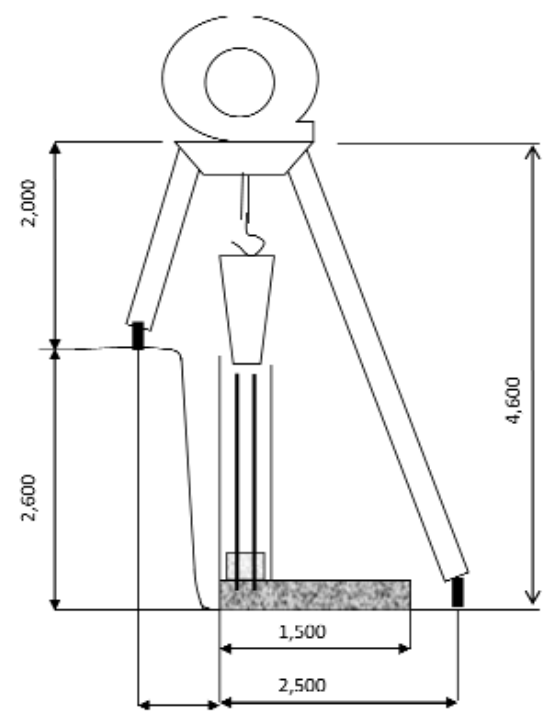

Рис. 10. Загальний вигляд зведення підпірної стіни с використанням "портала"

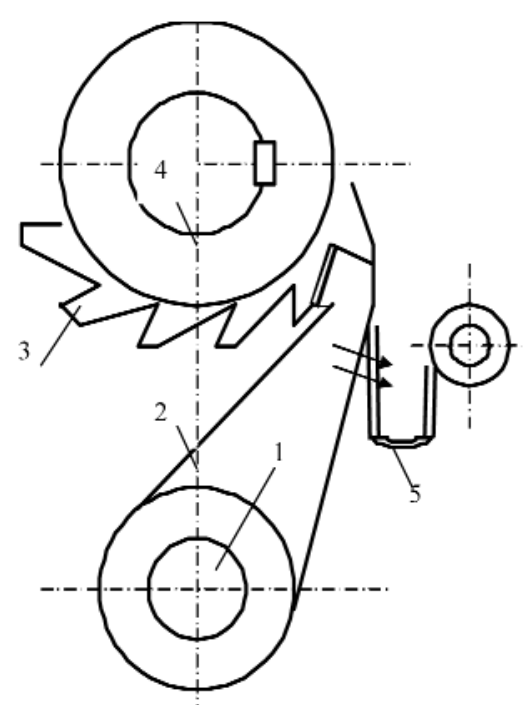

Рис. 9. Лебідки останови:

1 - вісь, 2 - собачка, 3 - храпове колесо, 4 - вал, 5 - пружина

грунту, що влаштовується у вигляді присипки до насипу замість підпірних стін.

Технологія зведення "контрбанкета" складається з наступних процесів:

Підготовчі роботи: 1 - Проведення інженерногеологічних вишукувань; $2-$ У нижній частині ковзання зсуву зрізується частина грунту; 3 - Доставка щебенів для зміцнення нижньої частини; 4 - Пошарове засипання схилу щебенями або гравієм; 5 - Пошарове ущільнення щебенів або гравію; 6 - Доставка дренувального грунту до місця; 7 - Пошарове засип-

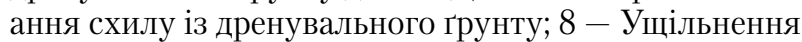
дренувального грунту; 9 - Влаштування контрбанкета ухилом 1:3

Техніко-економічні показники на пристрій контрбанкета становлять:

- Вартість робіт - 400 грн.

- Працезатрати робітників - 5,94 чіл.-год.

- Машинного часу - 5,94 маш.-год.

- Виробіток на один робітника -333 м²/зміну.

- Тривалість виконання робіт - 26 зміни.

Спосіб зміцнення схилів контрофорсами. Кон-

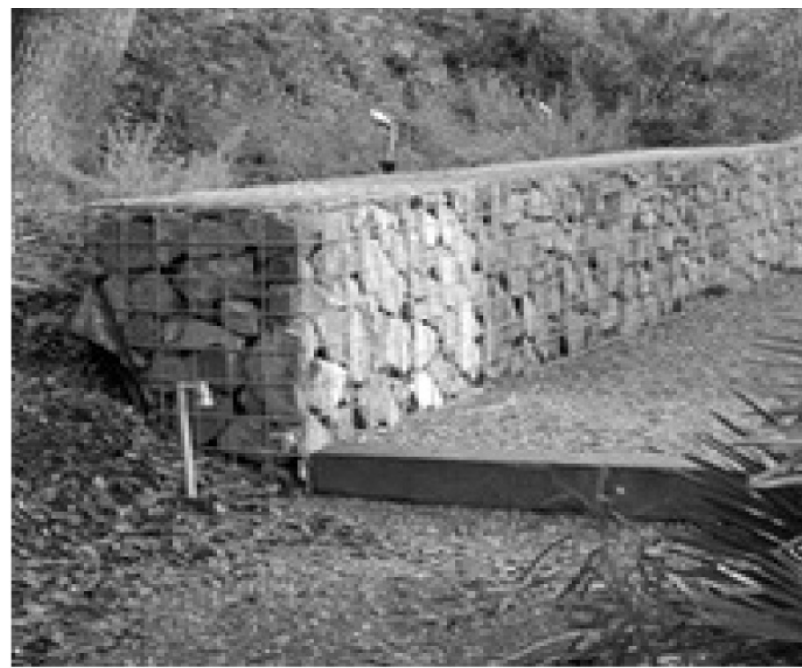

Рис. 11. Фото-фрагменти виготовлення габіонів 


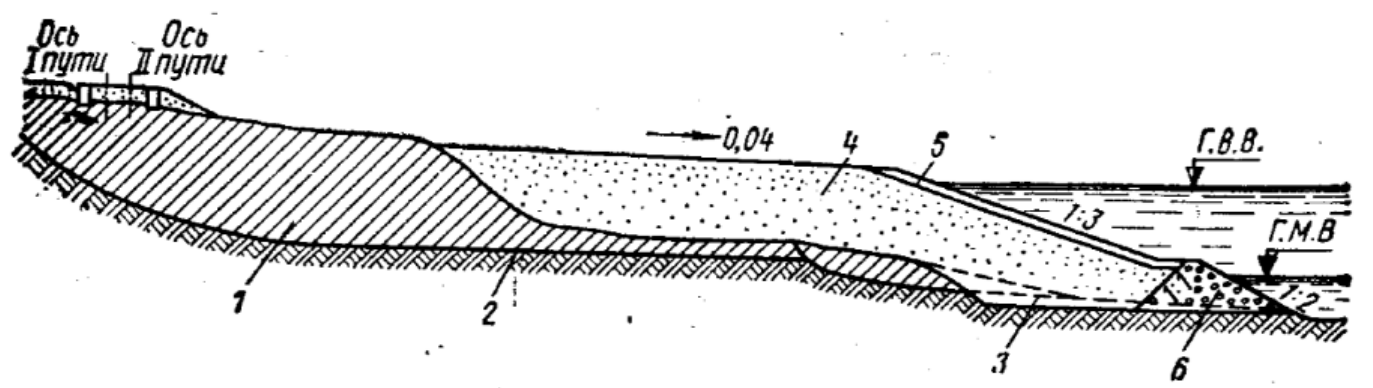

Рис. 12. Протизсувних контрбанкетів:

1 - зсув, 2 - поверхня ковзання, 3 - вирізана частина грунту, 4 - контрбанкет із дренуючого грунту, 5 - зміцнення укосу контрбанкетів, 6 - кам'яне накидання

трфорси є стовпи з бутового мурування на цементному розчині або довгі поздовжні (уздовж по оползневоу схилу) стрічки кам'яної кладки на розчині або насухо.

Технологія зведення "контрфорса" складається з наступних процесів: 1 - Зрізка укосу; 2 - Розробка грунту згідно із проектом; 3 - влаштування залізобетонного лотка; 4 - влаштування дерев'яних опалубок; 5 - Подача бетону в опалубку; $6-$ Ущільнення бетонної суміші; 7 - Розопалубування; 8 - влаштування дренажної труби; 9 - Укладання буту на розчині; 10 - влаштування цементної стяжки; 11 Розрівнювання поверхні.

Техніко-економічні показники на пристрій "контрфорсу" становлять:

- Вартість робіт - 450 грн

- Працезатрати робітників - 69,89 чіл.-година.

- Машинного часу - 120,5 маш.-година.

- Виробіток на один робітника $-2,8$ м²/зміну.

- Тривалість виконання робіт - 18 зміни.
Занесемо основні показники в загальну таблицю 4

Можна побачити з розглянутих варіантів за вартістю й тривалості для зміцнення схилу виходить контрбанкет. Але враховуючи умови будівництва цей вид виявився в нашому випадку неприйнятним. Тому порівнялися три варіанти: стіна в грунті, підпірна стіна й габіони. За розглянутими показниками був обраний другий варіант - підпірна стіна вартість 1 м - 7000 грн, а тривалість будівництва -36 змін.

\section{Висновки:}

На підставі літературних джерел і відомих сучасних способів зміцнення схилів були розроблені класифікації по методах і способам зведення.

Представлені методи зміцнення схилів дозволяють правильно підібрати способи з обліком їх області застосування, технологічних процесів і техніко-економічних показників.

У розглянутому прикладі найбільш ефективним виявився спосіб пристрою підпірної стіни з використанням розробленого встаткування.

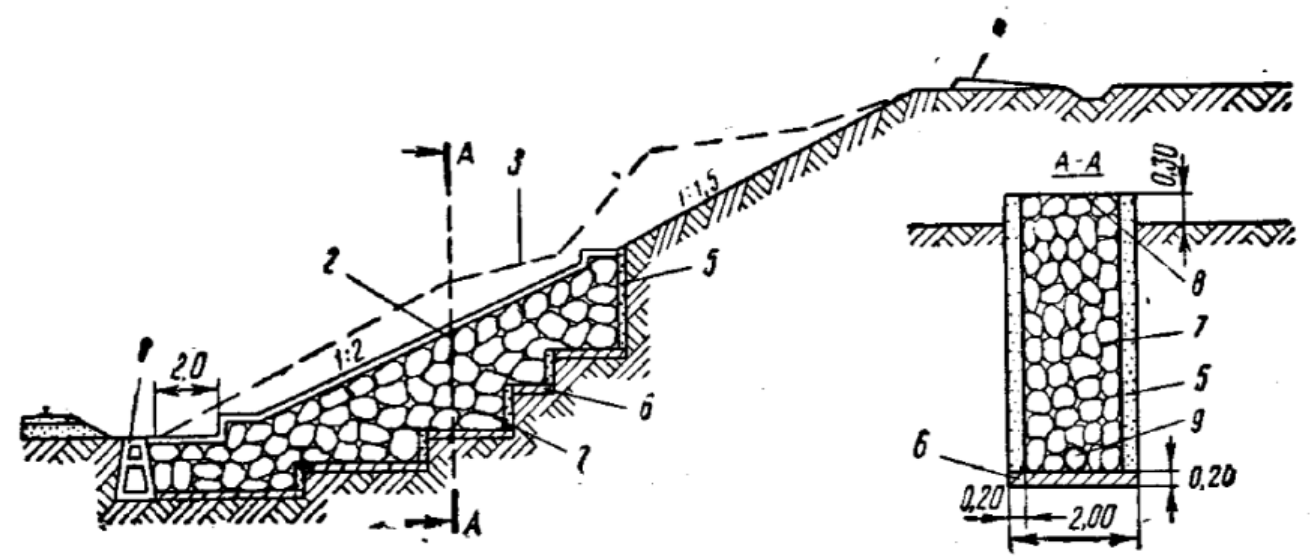

Рис. 13. Поперечний профіль контрфорсу для зміцнення укосу виїмки, що зсувається:

1 - залізобетонний лоток; 2 - контрфорсна дренажна проріз; 3 - контур уполаживаемого укосу; 4 - банкет; 5 грубозернистий пісок; 6 - бетон; 7 - суха кладка; 8 - цементне стягування; 9 - дренажна труба діаметром 15 см (труби може и не бути)

Таблица 4. Технико-экономические показатели по вариантам

\begin{tabular}{|l|l|l|c|c|c|c|c|}
\hline \multirow{2}{*}{ № } & \multirow{2}{*}{ найменування } & \multirow{2}{*}{$\begin{array}{c}\text { од. } \\
\text { вим. }\end{array}$} & $\begin{array}{l}\text { Стіна в } \\
\text { грунті }\end{array}$ & $\begin{array}{l}\text { Підпірна } \\
\text { стінка }\end{array}$ & Габионов & $\begin{array}{l}\text { контрбан } \\
\text { кета }\end{array}$ & $\begin{array}{l}\text { «контр } \\
\text { форса» }\end{array}$ \\
\hline 1 & Вартість робіт & грн & 9500 & 7000 & 10710 & 400 & 450 \\
\hline 2 & $\begin{array}{l}\text { Тривалість } \\
\text { виконання робіт }\end{array}$ & зміни & 68,8 & 36 & 15,4 & 26 & 16 \\
\hline 3 & $\begin{array}{l}\text { Виробіток на } \\
\text { одного робітника }\end{array}$ & м./зміна & 0,26 & 1,57 & 1,3 & 333 & 2,8 \\
\hline
\end{tabular}




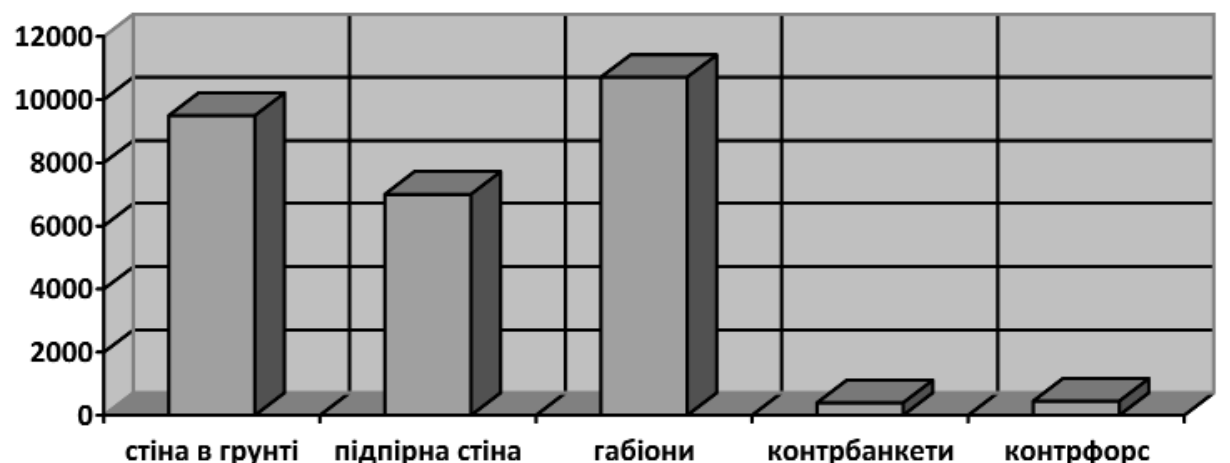

口вартість робіт, грн

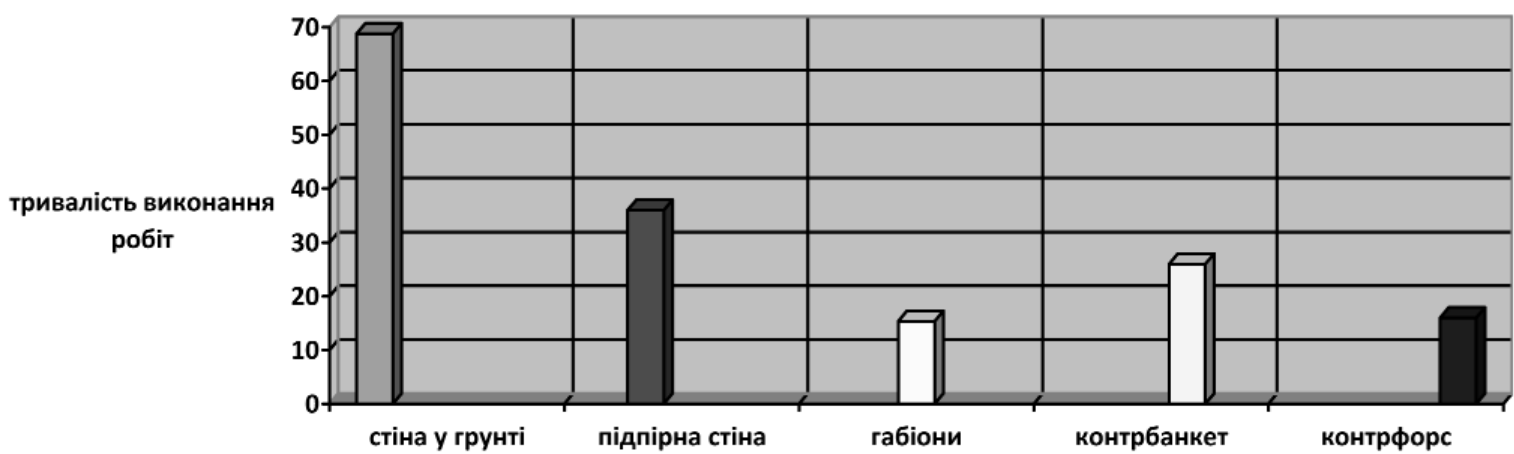

Рис. 15. Діаграма тривалості виконаних робіт від розглянутих способів

\section{Jimepamypa}

1. Энииклопедия по машиностроению XXL. оборудование, материаловедение, механика (Електронный ресурс)http://mash-xxl.info/page/

2. Емельянова Е.П. Основные закономерности оползневых процессов. М. Недра, 1972 г. - 312 c.

3. Корнилов А.Г., Петин А.Н., Сергеев С.В., Погорелов Ю.С., Тохтарь В.К., Присный А.В., Мартынова Н.А., Дроздова Е.А. Геоэкологические проблемы оптимизачии и биорекультивации отвалов вскрышных пород железорудных месторождений КМА. Белгород ИД "Белгород" НИУ "БелГУ" - 2013 г. - 124 c.

4. Патент № 97133 Система розгортання габіону. Хеселден Джеймс. Заявл. 17.12.2007, Опубл. 10.01.2012, Бюл. № 1

$-16 c .$. ил.

5. Глебчук Г. О. Аспекти комплексного впливу підтоплення земель та сейсмопроцесів на регіональну активізацію зсувоутворення/ Г.О. Глебчук, С.О. Яковлев // Будівельні конструкиії.: зб. наук. пр. - К. : ДП НДІПК, 2012. - Вип. 76. C. $300-306$.

6. Трофимчук А. Н. Надежность систем сооружение - грунтовое основание в сложных инженерно-геологических условиях/ А. Н. Трофимчук, В. Г. Черный, Г. И. Черный. - К. : ПолграфКонсалтинг, 2006. - 248 с.

7. Патент № 45279 Портал для виконання ремонтно-відновлювальних робіт. Галушко В.О. заявл. 21.05.2007; Опубл.

-10.11.2009, Бюл. № $21-10$ с..ил.

\section{References}

1. Entsyklopedyia po mashynostroenyiu XXL. oborudovanye, materyalovedenye, mekhanyka [Encyclopedia of mechanical engineering XXL. equipment, materials science, mechanics]. Available at: http://mash-xxl.info/page/ (accessed 5 February 2019).

2. Emelianova E.P. Osnovnye zakonomernosty opolznevykh protsessov [The main lawes of landslide processes]. Moscow, Nedra, 1972.312p.

3. Kornylov A.H., Petyn A.N., Serheev S.V., Pohorelov Yu.S., Tokhtar V.K., Prysnyi A.V., Martynova N.A., Drozdova E.A. Neoekolohycheskye problemy optymyzatsyy y byorekultyvatsyy otvalov vskryshnykh porod zhelezorudnykh mestorozhdenyi KMA I Geoecological problems of optimization and bioremediation of overburden dumps of KMA iron ore deposits]. Belhorod, "Belhorod" NYU "BelHU", 2013. 124 p.

4. Heselden D., e. a. System of deployment of gabion. Patent UA, no. 97133, 2012.

5. Hlebchuk H. O. Aspekty kompleksnoho vplyvu pidtoplennia zemel ta seismoprotsesiv na rehionalnu aktyvizatsiiu zsuvoutvorennia [Aspects of integrated influence of groundwater flood and seismic processes on regional activation of landslide formation]. Kyiv, Budivelni konstruktsii.: zb. nauk. pr. №76, 2012. 432 p.

6. Trofymchuk A. N. Nadezhnost system sooruzhenye - hruntovoe osnovanye v slozhnykh ynzhenerno-heolohycheskykh uslovyiakh [Reliability of systems construction - soil foundation in difficult engineering and geological conditions]. Kyiv, PolhrafKonsaltynh, 2006. 248 p.

7. Galuchko V., e. a. Portal dlia vykonannia remontno-vidnovliuvalnykh robit [Portal for repair and restoration works]. Patent UA, no. 45279, 2009 
В.А. Галушко

А.М. Галушко

И. В. Колодяжная

Д.Ю. Уваров,

А.С. Уварова

Одеськая государственная академия строительства и архитектуры, г. Одесса

\title{
СОВРЕМЕННЫЕ СПОСОБЫ УКРЕПЛЕНИЯ ГРУНТА ПРОТИВ СМЕЩЕНИЯ
}

\begin{abstract}
Аннотация. В статье рассмотрена проблема территории под частное жилищное строительство, которая сейчас является одной из актуальниших. В прошлом веке велось массовое строительство зданий и сооружений вблизи балок, водоемов. Для усадебного строительства участки выделялись неровные. По истечению ряда лет, в последствии, такие участки себя хорошо зарекомендовали. Поэтому малоэтажное строительство жильх поселений на склонах, на сегодняшний день является достойной альтернативой. Несвоевременные ремонты трубопроводов, выбрасывание мусора в близлежащие балки и, как следствие, подъем уровня грунтовых вод привели к возникновению оползней на таких территориях. Целью данной статьи является выбор эффективного метода закрепления склона от оползней. Поэтому задача сводится к выбору эффективной технологии для укрепления грунта против смещения.
\end{abstract}

Ключевые слова: современные технологии закрепления грунтов, способы и методы укрепления грунтов, смещение.

V. Halushko,

A. Halushko,

I. Kolodyazhna

D. Uvarov

A. Uvarova

Odessa State Academy of Civil Engineering and Architecture Odessa

\section{MODERN METHODS OF STRENGTHENING THE SOIL FROM MOVEMENT}

\begin{abstract}
The problem of territory under private housing construction is currently one of the most urgent in the article was shown. In the last century there was mass construction of buildings and constructions near beams, reservoirs. For the construction of the mansion were provided areas with uneven surface. For many years such territories have proven themselves well. Therefore low-rise construction of residential settlements on the slopes to date is a worthy alternative. The untimely repair of pipelines the dumping of garbage in adjacent girders and consequently the rise of groundwater levels led to landslides in such areas. The aim is selecting an effective method for fixing the slope from landslides. Therefore the task is to choose an effective technology to strengthen the soil against landslide.
\end{abstract}

Key words: modern technologies of consolidation of soils, methods and methods of strengthening of soils, landslide. 